\title{
Reseña de Antonio Castillo Gómez, Leer y oír leer. Ensayos sobre la lectura en los Siglos de Oro, Madrid/Frankfurt am Main, Iberoamericana/Vervuert, 2016, 231 pp. ISBN 978-84-8489-957-0
}

\section{Ofelia Rey Castelao}

Universidad de Santiago de Compostela ESPAÑA

ofelia.rey@usc.es

[Hipogrifo, (issn: 2328-1308), 5.1, 2017, pp. 513-516]

Recibido: 06-12-2016 / Aceptado: 18-01-2017

DOI: http://dx.doi.org/10.13035/H.2017.05.01.35

En la contracubierta de la obra que comentamos, Trevor J. Dadson escribe: «en este fascinante y ricamente documentado libro, Antonio Castillo Gómez, uno de los mayores expertos en el tema, explora todas las facetas de la lectura en los Siglos de Oro, desde la lectura en solitario a la lectura en voz alta, pasando por la lectura erudita y anotada, la lectura en las celdas de la Inquisición y en comunidades religiosas, y la lectura en la calle». Siendo el profesor Dadson una autoridad en este ámbito temático y en el período que Castillo aborda, no se podría hacer un comentario más ajustado ni más oportuno al respecto de un libro en que el autor se plantea preguntas clave sobre las prácticas lectoras de los siglos XVI y XVII: qué, cómo y dónde leyeron los hombres y mujeres en la España del Siglo de Oro y qué significados tuvieron los libros y la lectura para quienes tenían esta destreza y podían acceder a los libros.

En esta nueva publicación, Antonio Castillo presenta reunidos varios artículos publicados años atrás y que fueron objeto de sendas ediciones en Italia - Leggere nella Spagna Moderna. Erudizione, religiosità e svago, Bologna, Pàtron, 2013- y Portugal - Livros e leituras na Espanha do Século de Ouro, Cotia, Ateliê Editorial, 2014-, lo que nos da una idea de la proyección de la obra. La edición en castellano añade un capítulo sobre lectura y autobiografia que había salido en una publicación colectiva. Se trata, por lo tanto, de una recopilación que el autor ha orientado inteligentemente para lograr una unidad temática que redondea y homogeneíza la perspectiva múltiple con la que aborda el ámbito de la lectura y de los lectores en la España de los Siglos de Oro. 
A esto ayudan las páginas finales dedicadas a las fuentes empleadas en los diferentes capítulos, tanto manuscritas - procesos inquisitoriales, sobre todo- como impresas -textos doctrinales, autobiografías-, la amplia bibliografía y el índice de nombres, obras y lugares citados en el texto. No es esta una información complementaria y propia del trámite editorial, sino que permite comprobar la abundancia y diversidad documental que se exhibe a lo largo del libro, contrastada y sometida a crítica hasta extraer lo que realmente sirve al autor para responder a lo que el título promete, esto es, leer y oír leer y las prácticas y experiencias socialmente diversificadas que comportan ambas dimensiones. Permite también constatar que las referencias bibliográficas responden a una bien pensada selección que combina diferentes tradiciones y tendencias metodológicas, faltando si acaso, una mayor atención a las de fundamentación serial.

Y es que, en efecto, lo que este libro propone no emplea el método de raigambre francesa del uso masivo de recuentos o inventarios notariales para localizar a los poseedores de libros o los objetos cotidianos de la escritura, ya que no es esa su intención, sino ir más allá de la propiedad y de esas presencias materiales -libros, cuadernos, escrituras - en las casas o en las instituciones, para abordar las prácticas de la lectura que situaban al lector - o a quien oía leer- en su espacio real. Por eso mismo no hay cifras, sino un conjunto variado de indicios que se ensamblan en un todo significativo, dentro de lo minoritaria y socialmente selectiva que era en los siglos XVI y XVII la destreza de leer; oír leer y entender lo que se oía era algo menos selectivo, pero no sin limitaciones, como las impuestas por el dominio que cada individuo o colectivo tuviera del idioma de la cultura escrita.

Los seis capítulos del libro se ordenan para conseguir ese todo. En el primero, que lleva en su título una referencia al Quijote - «del donoso y grande escrutinio» (p. 19) - se abordan y analizan las opiniones que en aquellos dos siglos se manifestaban al respecto de los libros y de las lecturas y los clasificaban según parámetros morales y de utilidad social, dejando fuera, ya no lo «inmoral», sino lo que era entretenimiento, y que ponían de un lado aquello que se consideraba malo -por lascivo, venenoso, transgresor, o solo superficial-y de otro, lo «correcto», entendido por lo que convenía a la construcción del «buen ciudadano» y del «buen cristiano». Un escrutinio que perseguía lo socialmente dañino desde el punto de vista moral y que en último término ponía en cuestión el valor de la proliferación de impresos de todo tipo y la «excesiva lectura».

El capítulo siguiente se dedica a la lectura erudita, que conllevaba frecuentemente tomar notas, de ahí que un epígrafe se titule «del libro al cuaderno» (pp. 55-63) y otro se ocupe «del orden de las notas y la composición de los cuadernos» (pp. 64-70). En estas páginas, los lectores no lo son por «pasatiempo» o entretenimiento, sino que buscaban hacerse con el saber ajeno, con conocimientos o con modelos de comportamiento, esto es, lo que remitía al oficio, en unos casos, al beneficio en otros y en los demás, al interés; lo que los unía era que para todos era más importante «leer, que no tener» libros y manuscritos o no tenerlos en grandes números, sino poder acceder a ellos y aplicarles luego la lectura privada, segura- 
mente en silencio, intensiva, analítica y reflexiva, extrayendo notas que sintetizaban lo que interesaba a ese tipo de lector en un momento determinado.

Vinculado con el sentido de esas páginas, el tercer capítulo se mantiene en espacios cerrados y sus protagonistas siguen siendo individuos, no colectivos. Bajo un sugerente título - «pasiones solitarias», pp. 73-90-, se esconden las sórdidas mazmorras de las cárceles inquisitoriales. La diferencia fundamental con respecto a la lectura privada del capítulo anterior está en que la falta de libertad física y la soledad siniestra de los lectores, convierten a la lectura en una cierta liberación; por muchas limitaciones que se impusiesen a los reos, leer podía servir para tres fines complementarios: tener algún «consuelo» de tipo espiritual o moral, obtener una mínima dosis de entretenimiento o distracción o incluso para organizar la defensa ante los jueces. Antonio Castillo ya ha dado muchas muestras de su dominio sobre ese ambiente opresivo, especialmente escaso en fuentes documentales, y especialmente arduo en el tratamiento de los datos, como todo lo relacionado con los mecanismos de la represión.

En los siguientes capítulos el autor nos conduce de las lecturas individuales y sin intermediarios a las compartidas. En el cuarto, titulado «leer en comunidad» (pp. 91-120), a primera vista podrían desorientar los sub-epígrafes, dedicados a «una secta de Mahoma» - con referencia a los moriscos-, las «mujeres bajo sospecha» -las beatas - y las sometidas a «vivir y leer en observancia»-las monjas-. Pero Castillo señala que son unos cuantos testimonios de los muchos posibles, que le permiten analizar «distintas comunidades textuales o de interpretación, efectivas y no invisibles» (p. 93), con nexos comunes como las lecturas en voz alta -y por lo tanto, a través de intermediarios - o sujetas a una regla o a una norma. En estas páginas adquieren un singular protagonismo las mujeres -algo parecido sucede en el sexto-, pero lo realmente importante es que se consigue exponer y analizar «las maneras que rigieron la apropiación en materia espiritual en las tres comunidades consideradas, distintas entre sí pero ejemplares en cuanto a la función dada a la lectura en otros contextos y grupos similares» (p. 120).

Cambiando completamente el escenario, el capítulo quinto nos conduce a «leer en la calle», a las gradas y plazas, y a buscar «algo más que libros», pasando a los folletos, gacetas, panfletos, pasquines, edictos, carteles, etc., impresos muchos pero también manuscritos, que contenían tanto canciones y coplas como avisos y noticias, sucesos reales o ficticios, órdenes y rastros de desobediencia, chismes y curiosidades. El autor busca estas otras modalidades de lectura que vinculan lo escrito con lo visual y lo oral, un complejo entramado de comunicación fundamentalmente urbano. El dominante mundo rural tenía muchas menos opciones, salvo quizá en las zonas de hábitat concentrado de La Mancha, que Antonio Castillo conoce tan bien, y en otros territorios castellanos; debe tenerse en cuenta que los mecanismos y resortes de la difusión funcionaban en el rural disperso de forma muy diferente, más todavía si la lengua de comunicación era otra, como sucedía en el Norte.

El libro termina con un capítulo en el que se trata la lectura a través de los textos autobiográficos, en los que Antonio Castillo busca el «estatuto dado a los libros y al 
acto de leer» y «la significación que el acto de leer adquiere en la vida según se narra y representa» (p. 153) en cada uno de esos relatos. Es decir, el autor muestra su cautela frente a aquellos textos de auto-justificación o auto-promoción en los que la imagen del lector o de la lectora se magnifica para dar impresión de altura cultural o de espiritualidad rigurosa y reflexiva. Lo que estas páginas analizan va desde el primer acercamiento a la lectura en años infantiles, a los libros leídos, comprados o intercambiados, a las lecturas compartidas y, en definitiva, a la incorporación de lo leído a la vida. Afloran en este capítulo las desigualdades y distancias entre quienes «acreditan una práctica de la lectura más o menos habitual» y quienes «solo la refieren de manera ocasional» (p. 155); fuera de esos círculos - no necesariamente privilegiados ni ricos - estaba sin duda una mayoría social para la que el acceso a la lectura era todavía más difícil.

El libro que comentamos es más que un conjunto de ensayos sobre la lectura en los Siglos de Oro. Es un recorrido bien documentado y convincente sobre un campo en el que el autor ha demostrado su dominio muchas veces y siempre bien. La escritura fácil y de calidad con la que se construye la obra colabora a su comprensión y a la asimilación de sus muchas aportaciones. 